\title{
Development and evaluation of fast-dissolving tablets of meloxicam- $\beta$-cyclodextrin complex prepared by direct compression
}

\author{
AIMAN A. OBAIDAT ${ }^{1 *}$ \\ RANA M. OBAIDAT ${ }^{2}$ \\ ${ }^{1}$ Department of Pharmaceutical \\ Technology, Faculty of Pharmacy \\ Jordan University of Science and \\ Technology, P.O. Box 3030, Irbid-Jordan \\ 2 Department of Pharmaceutical Sciences \\ Faculty of Pharmacy, Alzaytoonah Private \\ University of Jordan, Amman-Jordan
}

Accepted December 27, 2010

\begin{abstract}
The aim of this study was to prepare fast-dissolving tablets of meloxicam after its complexation with $\beta$-cyclodextrin $(\beta-C D)$ and to investigate the effect of using different superdisintegrants on the disintegration and release of meloxicam from the tablets. A complex of meloxicam with $\beta$-CD was prepared by spray drying and then compressed in the form of tablets utilizing the direct compression technique. Three superdisintegrants were employed at various levels - sodium starch glycolate, croscarmellose sodium, and crospovidone. Co-spray dried micro-crystalline cellulose and mannitol (Avicel HFE-102) were used as diluents in the tablets. Prior to compression, the pre-compression parameters showed satisfactory flow properties. Post-compression parameters showed that all tablet formulations had acceptable mechanical properties. Wetting and disintegration times were prolonged by increasing the level of sodium starch glycolate in the tablets. This was attributed to the formation of a viscous gel layer around the tablets by sodium starch glycolate whereas this effect was not observed with croscarmellose sodium and crospovidone. Dissolution studies showed fast release of meloxicam except in tablets containing a high level of sodium starch glycolate. Complexation of meloxicam with $\beta$-CD significantly improved the solubility of the drug and improved the mechanical properties of tablets produced by direct compression.
\end{abstract}

Keywords: meloxicam, sodium starch glycolate, croscarmellose sodium, crospovidone, $\beta$-cyclodextrin

Difficulty in the swallowing of conventional tablets by geriatric and pediatric patients may lead to poor patient compliance and ineffective therapy. To overcome such problems, a new dosage form has been introduced, known as fast-dissolving tablets. In most cases, these tablets disintegrate or dissolve in the oral cavity without the need for

\footnotetext{
* Correspondence; e-mail: aobaidat@just.edu.jo
} 
A. A. Obaidat and R. M. Obaidat: Development and evaluation of fast-dissolving tablets of meloxicam- $\beta$-cyclodextrin complex prepared by direct compression, Acta Pharm. 61 (2011) 83-91.

water or chewing. Fast-dissolving tablets are not only suitable for people with swallowing difficulties, they are also ideal for active people. This new dosage form provided the benefits of enhanced patient compliance, rapid onset of action, and increased bioavailability. Therefore, there are a number of fast-dissolving formulations in the market now and the technology is still improving (1).

The basic principles in the development of fast-dissolving tablets are the use of superdisintegrants or maximization of the porous structure of tablets. Several techniques have been applied in the development of fast-dissolving tablets, such as melt granulation (2), phase transition process (3), sublimation (4), spray drying (5), freeze drying (6), in addition to tablet moulding and direct compression (7).

Tablets produced by freeze drying show a very porous structure, so there is quick penetration of saliva into the pores once they are placed in the oral cavity. However, the main disadvantages of such tablets are lack of physical resistance and limited ability to incorporate higher amounts of the active drug, as well as a high cost of production. Direct compression is assumed to be a better option for the production of fast-dissolving tablets with satisfactory disintegration times. This is the most cost effective technology for the production of fast-dissolving tablets because it does not require special equipment with a limited number of processing steps.

Meloxicam is an enolic acid, non-steroidal anti-inflammatory drug, which is mainly indicated for osteoarthritis and rheumatoid arthritis and is characterized by poor and $\mathrm{pH}$ dependent water solubility (8). Several techniques have been used to improve the solubility and dissolution characteristics of meloxicam, mainly by its complexation with cyclodextrins $(9,10)$. Meloxicam- $\beta$-CD complex has been prepared by spray drying and characterized according to a previously published procedure from our laboratory (9). In particular, it has been characterized by differential scanning calorimetry. Fourier transform infrared spectroscopy, X-ray diffraction and intrinsic dissolution. Thus, the present investigation was conducted to prepare optimized fast-dissolving tablets of meloxicam after its complexation with $\beta-C D$ using various superdisintegrants and using Avicel HFE-102 as a diluent. The novelty in this study is demonstrated in optimizing the solubility of meloxicam by complexation with $\beta-C D$ and then formulating it into fast-dissolving tablets. It is likely that a porous hydrophilic matrix will easily pick up the disintegrating medium, break, and dissolve quickly, resulting in fast release and rapid dissolution of the drug, and hence improved absorption and bioavailability.

\section{EXPERIMENTAL}

\section{Materials}

Meloxicam, pharmaceutical grade, was a gift from the Jordanian Pharmaceutical Manufacturing Company (JPM Co., Jordan). $\beta$-Cyclodextrin ( $\beta$-CD), aspartame, magnesium stearate, and talc were form Sigma Chemical Co. (USA), sodium starch glycolate (SSG) (Primojel) from DMV International (The Netherlands), crospovidone (CP) from BASF chemicals (USA), croscarmellose sodium (CCS) and Avicel HFE-102 from FMC BioPolymer (USA). Avicel HFE-102 is a new high functionality excepient made up of co-spray dried microcrystalline cellulose and mannitol. All reagents were of pharmaceutical grade and were used as received. 
A. A. Obaidat and R. M. Obaidat: Development and evaluation of fast-dissolving tablets of meloxicam- $\beta$-cyclodextrin complex prepared by direct compression, Acta Pharm. 61 (2011) 83-91.

\section{Methods}

Preparation of meloxicam- $\beta-C D$ complex. - Meloxicam- $\beta-C D$ complex was prepared using the spray drying method according to a previously published procedure from our laboratory (9). Briefly, a solution containing equal molar amounts of meloxicam and $\beta$-CD was prepared in $200 \mathrm{~mL}$ borate buffer of $\mathrm{pH} 10$. Then, the drug was precipitated by lowering the solution $\mathrm{pH}$ to 2.8 by adding $0.2 \mathrm{~mol} \mathrm{~L}^{-1} \mathrm{HCl}$ in order to produce smaller particles of meloxicam and thus a more soluble drug. Finally, the $\mathrm{pH}$ of the solution was raised to 7.4 by adding $0.2 \mathrm{~mol} \mathrm{~L}^{-1} \mathrm{NaOH}$. The solution was then spray dried using a mini spray dryer (Büchi 190 mini spray dryer, Germany). The inlet and outlet temperatures were 134 and $84{ }^{\circ} \mathrm{C}$, respectively. Characterization of the complex regarding stoichiometry and stability was proved previously (9) and no further investigations were performed on the meloxicam- $\beta-C D$ complex.

Preparation of tablets. - An amount of the complex (meloxicam- $\beta-C D$ ) equivalent to $15 \mathrm{mg}$ of meloxicam was blended with directly compressible diluents and superdisintegrants in a plastic bag for 20 minutes. Magnesium stearate, aspartame and talc were passed through a $0.25-\mathrm{mm}$ sieve, mixed and then blended with the initial mixture in the plastic bag. The blend was then compressed using a single-punch tablet press (Erweka, Germany) and using 9-mm diameter circular punches with flat faces under compression of $2 \times 10^{3} \mathrm{~kg}$. Machine settings were adjusted to produce tablets having the same hardness and mass. Nine formulations were prepared with a target mass of $250 \mathrm{mg}$ (formulations codes F1-F9). The composition of these formulations is shown in Table I. Prior to compression, powder blends were evaluated for pre-compression parameters like Hausner's ratio [tapped/bulk density ratio using a tapped volumeter apparatus (Copley Scientific, UK)], Carr's compressibility index (11), and static angle of repose. To measure the angle of repose, $10 \mathrm{~mL}$ of powder was poured through a glass funnel onto a flat surface and the angle to the horizontal was measured. The measurements were performed in triplicate.

Table I. Composition of fast-dissolving tablets of meloxicam

\begin{tabular}{lccccccccc}
\hline Ingredient $(\mathrm{mg})^{\mathrm{a}}$ & $\mathrm{F} 1$ & $\mathrm{~F} 2$ & $\mathrm{~F} 3$ & $\mathrm{~F} 4$ & $\mathrm{~F} 5$ & F6 & F7 & F8 & F9 \\
\hline Complex $^{\mathrm{b}}$ & 23.8 & 23.8 & 23.8 & 23.8 & 23.8 & 23.8 & 23.8 & 23.8 & 23.8 \\
Avicel HFE-102 & 214.2 & 209.2 & 204.2 & 214.2 & 209.2 & 204.2 & 214.2 & 209.2 & 204.2 \\
SSG & 5 & 10 & 15 & - & - & - & - & - & - \\
CCS & - & - & - & 5 & 10 & 15 & - & - & - \\
CP & - & - & - & - & - & - & 5 & 10 & 15 \\
Aspartame & 5 & 5 & 5 & 5 & 5 & 5 & 5 & 5 & 5 \\
Talc & 1 & 1 & 1 & 1 & 1 & 1 & 1 & 1 & 1 \\
Mg-stearate & 1 & 1 & 1 & 1 & 1 & 1 & 1 & 1 & 1 \\
Total mass & 250 & 250 & 250 & 250 & 250 & 250 & 250 & 250 & 250 \\
\hline
\end{tabular}

a A batch of 80 tablets was prepared from each formulation.

$\mathrm{b}$ Amount of complex (meloxicam- $\beta-\mathrm{CD}$ ) is equivalent to $15 \mathrm{mg}$ of meloxicam. 
Characterization of tablets. - Physical properties of the tablets were determined according to the USP 24 methods (12). Mass variation was performed on 20 tablets selected at random. Hardness of the tablets was measured by recording the force to fracture a tablet on a hardness tester for 6 tablets from each formulation (Copley Scientific). Friability was determined using an Erweka friability tester for 20 tablets at $100 \mathrm{rpm}$ for 4 minutes. Six tablets were tested from each formulation for disintegration time at $37 \pm 0.5^{\circ} \mathrm{C}$ in water. To investigate the wetting time of the tablets, a twice folded piece of tissue paper was placed in a small Petri dish containing $5 \mathrm{~mL}$ of distilled water. A tablet was placed on the paper and the time required for complete wetting of the tablet was recorded in seconds. For determination of drug content, a total of 10 tablets were weighed and powdered. A powder mass equivalent to $15 \mathrm{mg}$ of meloxicam was weighed, dissolved in methanol and filtered. The filtrate was collected, diluted suitably and analyzed for the content of meloxicam by UV-spectroscopy at $362 \mathrm{~nm}$ (Cintra $5 \mathrm{UV}$-visible spectrophotometer, Australia) (9).

In vitro release study. - The in vitro dissolution study was carried out according to the USP 24 specifications (12) with Apparatus II $(n=6)$ using an Erweka dissolution apparatus DT-D6. The dissolution medium consisted of $900 \mathrm{~mL}$ of $\mathrm{pH} 6.8$ phosphate buffer solution maintained at $37 \pm 0.5{ }^{\circ} \mathrm{C}$ and stirred at $50 \mathrm{rpm}$. Aliquot samples (5 mL) were withdrawn every minute, filtered through a $0.45-\mu \mathrm{m}$ membrane filter (Millipore, USA) and replaced by an equivalent volume of fresh dissolution medium. The samples were suitably diluted and the amount of the drug dissolved was analyzed spectrophotometrically at $362 \mathrm{~nm}$.

\section{RESULTS AND DISCUSSION}

Prior to compression, the powder blends were evaluated for the most important parameters referring to flowability and compression. Table II shows the pre-compression parameters of the powder blends used in the compression of meloxicam fast-dissolving tablets. The blends were found to have excellent flowability as determined by Hausner's ratio, compressibility index and angle of repose. The compressibility index ranged from 12.3 to $15.1 \%$. Compressibility index values of up to $15 \%$ generally indicate excellent flow properties in regard to compressibility-flowability correlation data. Hausner's ratio was approximately higher than 1 and the angle of repose ranged from $18-21^{\circ}$ for all the formulation blends. Therefore, the values of pre-compression parameters were within the prescribed limits and indicated excellent flow properties.

Avicel HFE-102 was used in the formulation of meloxicam fast-dissolving tablets under study. It provides a synergistic functionality over the individual or dry blended components (cellulose and mannitol) with better flow, compaction, and disintegration properties compared to traditional microcrystalline cellulose grades. It is intended for utilization in direct compression of tablets and instant release oral solid dosage forms (13).

The post-compression parameters such as hardness, friability, drug content, and tablet mass variations are presented in Table III. The hardness test indicated good mechanical strength with non-significant differences in all formulations. It is assumed that the presence of $\beta-C D$ in the formulation resulted in lower friability of the tablets. It has 
A. A. Obaidat and R. M. Obaidat: Development and evaluation of fast-dissolving tablets of meloxicam- $\beta$-cyclodextrin complex prepared by direct compression, Acta Pharm. 61 (2011) 83-91.

Table II. Pre-compression parameters of the powder blends used in the preparation of meloxicam fast-dissolving tablets

\begin{tabular}{cccc}
\hline Formulation & Hausner's ratio $^{\mathrm{a}}$ & ${\text { Compressibility index }(\%)^{\mathrm{a}}}$ & ${\text { Angle of repose }\left(\theta,{ }^{\circ}\right)^{\mathrm{a}}}^{\mathrm{a}}$ \\
\hline F1 & $1.13 \pm 0.05$ & $13.75 \pm 0.11$ & $21.35 \pm 0.06$ \\
F2 & $1.12 \pm 0.04$ & $13.87 \pm 0.18$ & $21.86 \pm 0.08$ \\
F3 & $1.10 \pm 0.07$ & $14.39 \pm 0.16$ & $20.55 \pm 0.11$ \\
F4 & $1.15 \pm 0.05$ & $12.25 \pm 0.18$ & $18.28 \pm 0.15$ \\
F5 & $1.17 \pm 0.09$ & $15.08 \pm 0.13$ & $19.15 \pm 0.11$ \\
F6 & $1.19 \pm 0.11$ & $14.47 \pm 0.91$ & $21.45 \pm 0.14$ \\
F7 & $1.22 \pm 0.09$ & $13.75 \pm 0.16$ & $20.85 \pm 0.09$ \\
F8 & $1.18 \pm 0.12$ & $13.83 \pm 0.15$ & $19.74 \pm 0.12$ \\
F9 & $1.14 \pm 0.08$ & $14.22 \pm 0.12$ & $20.39 \pm 0.09$ \\
\hline
\end{tabular}

a Mean $\pm \mathrm{SD}, n=3$.

been shown by other investigators that the friability of tablets decreased as the concentration of $\beta$-CD was increased (14). This has been attributed to the water of crystallization present in $\beta-C D$ which helps in the binding of particles and production of stronger tablets (15). All the tablets showed good mechanical resistance, as indicated by the friability test where it was less than $1 \%$ for all tablets. Drug content was found to be consistent and almost uniform in all tablet formulations (>98\%) and no significant statistical mass variability was observed in the produced tablets. Therefore, our results, as indicated by the post-compression parameters presented in Table III, showed that an excellent degree of uniformity was achieved for all prepared tablet formulations.

Table III. Evaluation of meloxicam fast-dissolving tablets (post-compression parameters)

\begin{tabular}{|c|c|c|c|c|}
\hline Formulation & Hardness $\left(\mathrm{kg} \mathrm{cm}^{-2}\right)^{\mathrm{a}, \mathrm{b}}$ & Friability $(\%)^{\mathrm{a}, \mathrm{c}}$ & Drug content $(\%)^{\mathrm{a}, \mathrm{d}}$ & Mass $(\mathrm{mg})^{\mathrm{a}, \mathrm{c}}$ \\
\hline F1 & $3.6 \pm 0.1$ & $0.56 \pm 0.1$ & $100.8 \pm 1.2$ & $250.34 \pm 1.7$ \\
\hline $\mathrm{F} 2$ & $3.4 \pm 0.2$ & $0.55 \pm 0.1$ & $98.46 \pm 1.4$ & $250.26 \pm 1.1$ \\
\hline F3 & $3.3 \pm 0.1$ & $0.53 \pm 0.1$ & $99.86 \pm 1.2$ & $250.15 \pm 1.4$ \\
\hline F4 & $3.3 \pm 0.1$ & $0.51 \pm 0.2$ & $99.80 \pm 1.6$ & $249.92 \pm 1.9$ \\
\hline F5 & $3.5 \pm 0.2$ & $0.48 \pm 0.2$ & $99.26 \pm 1.3$ & $249.98 \pm 1.8$ \\
\hline F6 & $3.7 \pm 0.2$ & $0.56 \pm 0.1$ & $99.93 \pm 1.4$ & $250.12 \pm 1.9$ \\
\hline F7 & $3.5 \pm 0.1$ & $0.52 \pm 0.2$ & $100.6 \pm 1.3$ & $250.45 \pm 0.8$ \\
\hline F8 & $3.6 \pm 0.1$ & $0.58 \pm 0.2$ & $99.66 \pm 1.5$ & $250.24 \pm 1.8$ \\
\hline F9 & $3.8 \pm 0.2$ & $0.53 \pm 0.1$ & $99.13 \pm 1.6$ & $250.24 \pm 1.8$ \\
\hline
\end{tabular}

a Mean \pm SD.

b $n=6$, c $n=20, \mathrm{~d} n=10$. 
A. A. Obaidat and R. M. Obaidat: Development and evaluation of fast-dissolving tablets of meloxicam- $\beta$-cyclodextrin complex prepared by direct compression, Acta Pharm. 61 (2011) 83-91.

Table IV. Evaluation of wetting and disintegration times of meloxicam fast-dissolving tablets

\begin{tabular}{ccc}
\hline Formulation & Wetting time $(\mathrm{s})^{\mathrm{a}}$ & ${\text { Disintegration time }(\mathrm{s})^{\mathrm{a}}}^{\text {B }}$ \\
\hline F1 & $58 \pm 2$ & $36 \pm 1$ \\
F2 & $75 \pm 1$ & $42 \pm 1$ \\
F3 & $82 \pm 2$ & 56 \\
F4 & $65 \pm 1$ & 37 \\
F5 & $56 \pm 1$ & $32 \pm 1$ \\
F6 & $52 \pm 1$ & $26 \pm 1$ \\
F7 & $42 \pm 1$ & $35 \pm 1$ \\
F8 & $41 \pm 1$ & 31 \\
F9 & $38 \pm 1$ & 27 \\
\hline
\end{tabular}

a Mean $\pm \mathrm{SD}, n=6$.

The in vitro disintegration and wetting times are presented in Table IV. The in vitro disintegration times ranged from 26 to $56 \mathrm{~s}$ and the wetting times varied from 38 to $82 \mathrm{~s}$. However, regarding both the wetting and the in vitro disintegration times, it was observed that such times increased by increasing the amount of SSG in the tablet formulation. On the other hand, rapid disintegration times were obtained by increasing the level of CCS and CP in tablet formulations where the tablets disintegrated within shorter times compared to tablets containing SSG as a superdisintegrant. This indicated that increasing the level of SSG in the tablet had a negative effect on its disintegration time. Tablets containing SSG disintegrate due to rapid uptake of water and then rapid and enormous swelling into primary particles. At higher SSG levels, a viscous gel layer was formed around the tablets, which created a barrier to further penetration of the disintegration medium into the tablet. The effect of using higher concentrations of SSG was previously demonstrated to slow down the disintegration and drug release from tablets due to formation of a viscous barrier around the tablets (16). CCS and CP provided better disintegration times due to their better swelling abilities and rapid disintegration. CCS and CP have high capillary activity and pronounced hydration but little tendency to gel formation. Therefore, rapid disintegration and, hence, rapid dissolution is expected.

Wetting time is one of the indicators of fast disintegration and dissolution of fast-dissolving tablets (17). Our results also showed that the wetting time decreased by increasing the levels of CCS or CP in tablet formulations. However, when the level of SSG was increased in the tablet formulation from 2 to $6 \%$, the wetting time increased from 58 to $82 \mathrm{~s}$, respectively. These results are consistent with the disintegration times and can be also explained by slower migration of water into the tablet due to formation of a viscous barrier by increasing the level of SSG in tablets.

Dissolution of meloxicam is presented as cumulative percent released over time from tablets containing SSG, CCS and CP (Fig. 1). To examine the influence of superdisintegrants on the release of meloxicam from the tablets, the time for $50 \%$ release of meloxicam $\left(t_{50}\right)$ was taken into account. It can be noticed that $t_{50}$ increased by increasing the level of SSG in the tablets (Fig. 1a). It increased from almost 1 minute at the low level (2 

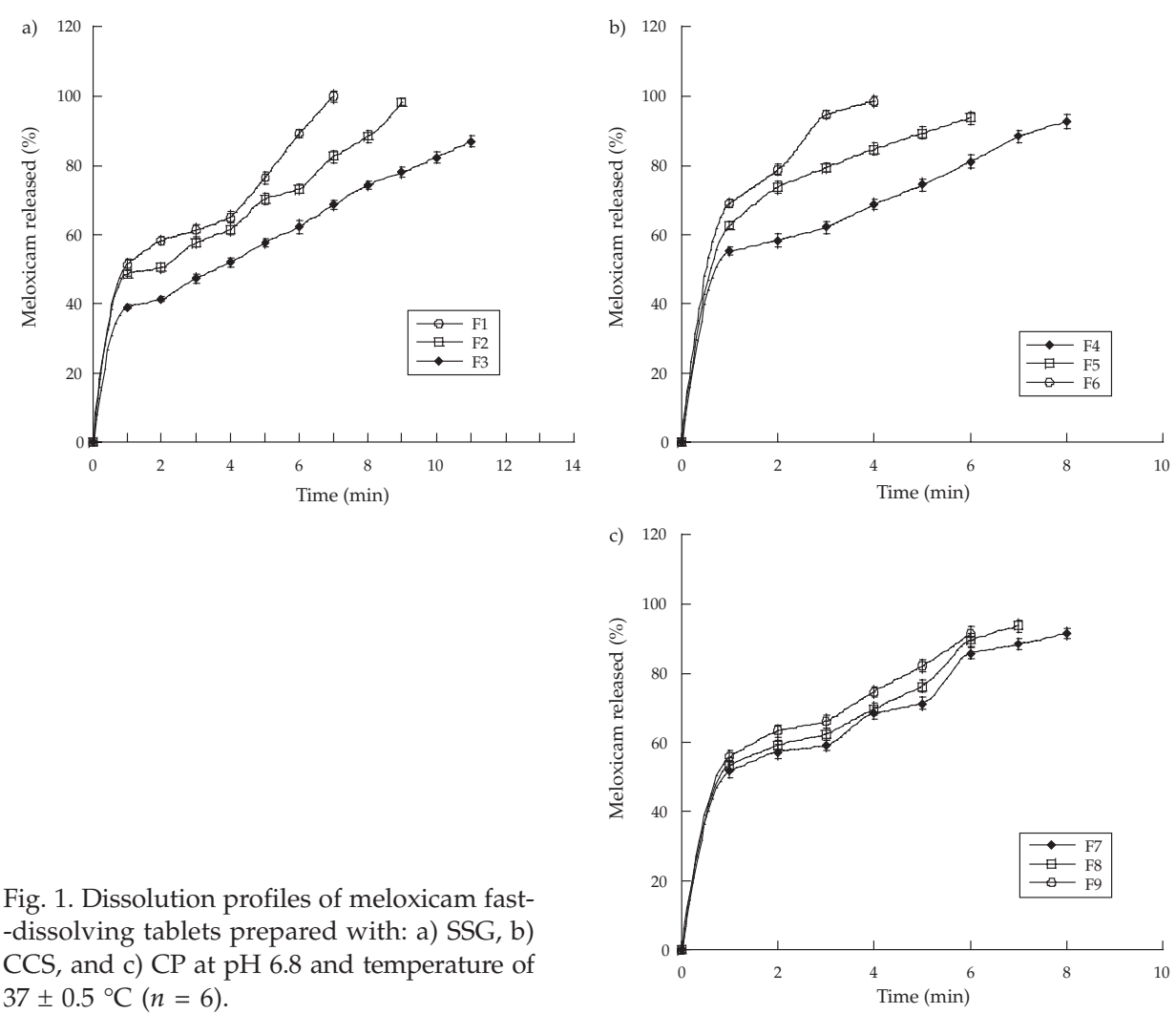

Fig. 1. Dissolution profiles of meloxicam fast-dissolving tablets prepared with: a) SSG, b) $\mathrm{CCS}$, and c) $\mathrm{CP}$ at $\mathrm{pH} 6.8$ and temperature of $37 \pm 0.5^{\circ} \mathrm{C}(n=6)$.

$\%)$ to more than 4 minutes at the high level of SSG (6\%). The $t_{50}$ was found to decrease by increasing the levels of CCS and CP in the tablets (Figs. $1 \mathrm{~b}$ and 1c, resp.). The $t_{50}$ was around 1 minute in both cases. Among all formulations studied, formulation F6 was found best regarding drug release, for it gave $98 \%$ release of the drug within 4 minutes. In addition, this formulation showed the shortest disintegration time of $26 \mathrm{~s}$. Formulation F6 contained $6 \%$ of CCS as superdisintegrant in addition to other basic excepients and had a drug content of $99.9 \%$ (Tables I and III).

\section{CONCLUSIONS}

The use of superdisintegrants for preparation of meloxicam fast-dissolving tablets by direct compression was found highly effective in this study. Optimized fast-dissolving tablets of meloxicam were prepared after complexation of meloxicam with $\beta$-CD. Dissolution of meloxicam from the tested formulations was fast, which can probably be attributed to its complextaion with $\beta$-CD. Furthermore, using $\beta$-CD facilitated the pharmaceutical preparation of the tablets. In particular, it enhances the compression behav- 
A. A. Obaidat and R. M. Obaidat: Development and evaluation of fast-dissolving tablets of meloxicam- $\beta$-cyclodextrin complex prepared by direct compression, Acta Pharm. 61 (2011) 83-91.

ior since it has contributed to good mechanical properties of the tablets when employed in the direct compression technique. Based on our results, formulation F6 with $99.9 \%$ drug and $6 \%$ of CCS as a superdisintegrant in addition to the other basic excipients seems to be a formulation of choice for further in vivo testing.

Acknowledgements. - This work was supported by the Deanship of Scientific Research, Jordan University of Science and Technology, Irbid-Jordan.

\section{REFERENCES}

1. F. Jamali and H. A. Aghazadeh, Rapidly dissolving formulations for quick absorption during pain episodes: ibuprofen, Int. J. Clin. Pharmacol. Ther. 46 (2008) 55-63.

2. Y. Dong, R. Kulkarni, R. J. Behme and P. N. Kotiyan, Effect of the melt granulation technique on the dissolution characteristics of griseofulvin, Int. J. Pharm. 329 (2007) 72-80; DOI: 10.1016/j. ijpharm.2006.08.029.

3. Y. Kuno, M. Kojima, S. Ando and H. Nakagami, Evaluation of rapidly disintegrating tablets manufactured by phase transition of sugar alcohols, J. Control. Release 105 (2005) 16-22; DOI: 10.1016/ j.jconrel.2005.01.018.

4. M. Gohel, M. Patel, A. Amin, R. Agrawal, R. Dave and N. Bariya, Formulation design and optimization of mouth dissolve tablets of nimesulide using vacuum drying technique, AAPS PharmSciTech. 5 (2004) Article 36; DOI: 10.1208/pt050456.

5. D. N. Mishra, M. Bimodal, S. K. Singh and S. G. Vijaya Kumar, Spray dried excipient base: a novel technique for the formulation of orally disintegrating tablets, Chem. Pharm. Bull. 54 (2006) 99-102; DOI: 10.1248/cpb.54.99.

6. I. S. Ahmad, M. M. Nafadi and F. A. Fatahalla, Formulation of fast dissolving ketoprofen tablets using freeze-drying in blister technique, Drug Dev. Ind. Pharm. 32 (2006) 437-442; DOI: 10.1080/ 03639040500528913.

7. L. Dobetti, Fast-melting tablets: Developments and technologies, Pharm. Technol. 5 (2001) 44-50.

8. P. Luger, K. Daneck, W. Engel, G. Trummlitz and K. Wagner, Structure and physicochemical properties of meloxicam, a new NSAID, Eur. J. Pharm. Sci. 4 (1996) 175-187; DOI: 10.1016/0928-0987(95)00046-1.

9. A. A. Obaidat, R. A. Khanfar and M. N. Khawam, The effect of $\beta$-cyclodextrin on the solubility and dissolution rate of meloxicam and investigation of the driving force for complexation using molecular modeling, J. Incl. Phenom. Macrocycl. Chem. 63 (2009) 273-279; DOI: 10.1007/s10847-008-9517-2.

10. A. A. Abdoh, M. I. El-Barghouthi, M. B. Zughul, J. E. Davies and A. A. Badwan, Changes in the conformational structure, microscopic and macroscopic pKas of meloxicam on complexation with natural and modified cyclodextrins, Pharmazie 62 (2007) 55-59.

11. K. R. Reddy, S. Mutalik and S. Reddy, Once-daily sustained release matrix tablets of nicorandil: formulation and in vitro evaluation, AAPS PharmSciTech. 4 (2003) Article 61; DOI: 10.1208/ pt040461.

12. United States Pharmacopoeia 24, National Formulary 19, USP Convention, Rockville (MD), USA, 2000.

13. N. Saigal, S. Baboota, A. Ahuja and J. Ali, Microcrystalline cellulose as a versatile excepient in drug research, J. Young Pharm. 1 (2009) 6-12; DOI:10.4103/0975-1483.51868. 
A. A. Obaidat and R. M. Obaidat: Development and evaluation of fast-dissolving tablets of meloxicam- $\beta$-cyclodextrin complex prepared by direct compression, Acta Pharm. 61 (2011) 83-91.

14. M. M. Ghorab, H. M. Abdel-Salam, M. A. El-Sayed and M. M. Mekhel, Tablet formulation containing meloxicam and $\beta$-cyclodextrin: Mechanical characterization and bioavailability evaluation, AAPS PharmSciTech. 5 (2004) Article 59; DOI: 10.1208/pt050459.

15. E. Fenyresi, O. Shirankura, J. Szejtli and T. Nagai, Properties of cyclodextrin polymer as a tableting aid, Chem. Pharm. Bull. (Tokyo) 32 (1984) 665-669.

16. N. Zhao and L. L. Augsburger, Functionality comparison of 3 classes of superdisintegrants in promoting aspirin tablet disintegration and dissolution, AAPS PharmSciTech. 6 (2005) Article 79; DOI: $10.1208 /$ pt060479.

17. D. Shukla, S. Chakraborty, S. Singh and B. Mishra, Mouth dissolving tablets: II. An overview of evaluation techniques, Sci. Pharm. 77 (2009) 327-341; DOI: 10.3797/scipharm.0811-09-02.

\author{
$S A \check{Z} E T A K$
}

\title{
Razvoj i vrednovanje lako topljivih tableta kompleksa meloksikama s $\beta$-ciklodekstrinom pripravljenih izravnom kompresijom
}

AIMAN A. OBAIDAT i RANA M. OBAIDAT

Cilj rada bio je priprava lako topljivih tableta kompleksa meloksikama s $\beta$-ciklodekstrinom $(\beta-C D)$ te ispitati utjecaj različitih superdezintegratora na raspadljivost tableta i oslobađanje meloksikama. Kompleks meloksikama s $\beta$-CD pripravljen je metodom sušenja sprejem, a komprimiran je $\mathrm{u}$ tablete metodom izravne kompresije. U pripravi tableta korištene su tri različite količine triju superdezintegratora: natrijev škrobni glikolat, natrijeva sol kroskarmeloze i krospovidon, dok su mikrokristalinična celuloza i manitol (Avicel HFE-102) upotrijebljeni kao punila. Predkompresijski parametri ukazivali su na zadovoljavajuću tečnost. Postkompresijski parametri pokazali su da sve tablete imaju prihvatljiva mehanička svojstva. Vlaženje i vrijeme raspadanja bilo je produljeno kada se povećao udio natrijevog škrobnog glikolata $u$ tabletama. To je pripisano stvaranju viskoznog sloja gela oko tableta, što nije primijećeno u pripravi tableta s natrijevom soli kroskarmeloze i krospovidonom. Oslobađanje meloksikama bilo je brzo iz svih tableta, osim iz tableta s visokim udjelom natrijeve soli škrobnog glikolata. Kompleksiranje meloksikama s $\beta$-CD značajno je povećalo topljivost lijeka i poboljšalo mehanička svojstva tableta.

Ključne riječi: meloksikam, natrijev škrobni glikolat, natrijeva sol kroskarmeloze, krospovidon, $\beta$-ciklodekstrin

Department of Pharmaceutical Technology, Faculty of Pharmacy, Jordan University of Science and Technology, P.O. Box 3030, Irbid-Jordan

Department of Pharmaceutical Sciences, Faculty of Pharmacy, Alzaytoonah Private University of Jordan Amman-Jordan 